\title{
Transarterial Chemo and Radioembolization (Yttrium90) of Hepatic Metastasis of Neuroendocrine Tumors: Single Center Experience
}

\author{
Fuat OZKAN ${ }^{1}$, Bora PEYNIRCIOGLU ${ }^{2}$, Barbaros E. CIL ${ }^{2}$, Nursel YURTTUTAN ${ }^{2}$, Suayib YALCIN \\ Ferhun BALKANCI ${ }^{2}$
}

\author{
Kahramanmaras Sutcu Imam University Faculty of Medicine, Department of Radiology, Kahramanmaras \\ ${ }^{2}$ Hacettepe University Faculty of Medicine, Department of Radiology, Ankara \\ ${ }^{3}$ Hacettepe University Faculty of Medicine, Department of Medical Oncology, Ankara, TURKEY
}

\begin{abstract}
The aim of this study was to present our single center experience with short $(<3$ months) and intermediate-term ( $>3$ months) follow-up results of patients who underwent transarterial radioembolization with yttrium-90 microsphere $(Y-90)$ or transarterial chemoembolization (TACE) for hepatic metastasis of neuroendocrine tumors (hmNETs). The results of 14 patients treated with either Y-90 or TACE were reviewed retrospectively. Clinical, laboratory, and imaging follow-up was performed. Efficacy was assessed by clinical and morphologic response. Survival was estimated by Kaplan-Meier analysis. Eight patients receiving 12 TACE treatments and 6 patients receiving 7 Y-90 treatments. Response rates were similar with two treatments at short-term follow-up, but there were a lower response rate and higher being progressive disease in the TACE group than Y-90 group at intermediate-term follow-up. However, progression-free survival was lower in Y-90 group (7.5 months) than TACE group (18 months). Regarding our limited experience, both Y-90 treatment and TACE have advantages and disadvantages in treatment of patients with hmNETs, however, randomized controlled studies, are needed.
\end{abstract}

Keywords: Yttrium-90, Chemoembolization, Liver, Neuroendocrine tumors

\section{ÖZET}

Karaciğer Metastazlı Nöroendokrin Tümörleri olan Hastalara Yapılan Yttrium-90 Mikroküre (Y-90) ile yapılan Radyoembolizasyon veya Transarteryel Kemoembolizasyon

Bu çalışmanın amacı karaciğer metastazlı nöroendokrin tümörleri olan hastalara yapılan yttrium-90 mikroküre (Y-90) ile yapılan radyoembolizasyon veya transarteryel kemoembolizasyon (TAKE) tedavilerinin kısa ( $<3$ ay) ve orta vadeli $(>3$ ay) tek merkez izlem sonuçlarımızı tartışmaktır. Y-90 veya TAKE ile tedavi edilmiş 14 hastanın klinik, laboratuar ve bilgisayarlı tomografileri retrospektif olarak değerlendirildi. Tedavinin etkinliği klinik ve morfolojik yanıt ile değerlendirildi. Sağkalım Kaplan-Meier analizi ile hesaplandı. Sekiz hastaya 12 TAKE, 6 hastaya 7 Y-90 tedavisi uygulandı. Yanıt oranları kısa vadeli izlemde iki tedavide benzer iken, orta vadede TAKE grubunda Y-90 grubuna göre tedaviye yanıt oranı düşük ve progresyon mevcuttu. Ancak, progresyonsuz sağkalım Y-90 grubunda (7.5 ay) TAKE grubuna (18 ay) göre daha düşüktü. Sınırı deneyimlerimize göre, karaciğer metastazlı nöroendokrin tümörleri olan hastalarda her iki tedavi seçeneğinin de avantaj ve dezavantajları olmakla birlikte, randomize kontrollü çalışmalara intiyaç vardır.

Anahtar Kelimeler: Yttrium-90, Kemoembolizasyon, Karaciğer, Nöroendokrin tümör 


\section{INTRODUCTION}

Neuroendocrine tumors (NETs) are rare neoplasms arised from the neuroendocrine system, so number of cases are low in the single center studies. ${ }^{1,2}$

Neuroendocrine tumors have a higher tendency for metastasizing to the liver. Presence of liver metastases is associated with poor prognosis. Without treatment, the rate of death within 5 years is nearly $80 \%$ in patients with NETs hepatic metastases. ${ }^{3}$ At the time of the diagnosis, the majority of patients with NETs (up to $75 \%$ ) already have liver metastases. $^{4}$

Surgical resection is the gold standard in the treatment of patients with hepatic metastasis of NET. However, in only $10 \%$ of cases, resection is possible due to diffuse or multiple involvement of the liver at the time of initial diagnosis. ${ }^{5}$ Systemic cytotoxic chemotherapy has limited success in the treatment of patients with NETs hepatic metastases and is associated with a significant toxicity. ${ }^{6}$ Somatostatin analogs are efficient in controlling symptoms in many of these patients, but eventually the disease becomes refractory to these agents. ${ }^{5}$

NETs liver metastases are highly hypervascular with arterial blood supply. Therefore, transarterial liver-directed therapies including TACE, and Y-90 treatments procedure for tumor regression and symptomatic improvement have proven effective in many patients with unresectable and symptomatic NETs hepatic metastases..$^{7-9}$ In this study, we present our single center experience with short and intermediate-term follow-up results of either Yttrium90 microspheres (Y-90) or TACE for hepatic neuroendocrine metastases.

\section{PATIENTS AND METHODS}

We retrospectively queried our interventional radiology database for all patients treated with either radioembolization using SIR Spheres ${ }^{\circledR}$ ( Sirtex Medical, Lane Cove, Australia) or TACE using different agents for biopsy-proven hepatic NET metastases between November 2006 and November 2009. Informed consent was obtained from all patients.

Inclusion criteria for the study were unresectable liver metastasis of neuroendocrine tumors; progressive tumor burden despite surgical or local ablative treatment modalities; adequate biochemical and coagulation parameters [total biluribine (TB) level less than $2 \mathrm{mg} / \mathrm{dL}$ and alanine transaminase (ALT) or aspartate transaminase (AST) levels less than five times of upper limit of normal]. Exclusion criteria were hepatic encephalopathy, massive ascites or were in clinical liver failure, uncontrolled coagulopathy or cardiac failure, immediate life-threatening major extra hepatic metastases and hepatopulmonary lung shunting $>20 \%$.

Total of 14 patients were included in this study, with a mean age 51.2 \pm 9.25 years; (range, 35-65 years). The site of the primary tumor was the small bowel in 1 patient $(7 \%)$, the pancreas in 6 patients (43\%), the large bowel/rectum in 2 patients (14\%), the stomach in 2 patients (14\%), and unknown in 3 patients $(21 \%)$ (Table 1$)$.

Eleven out of 14 patients had multifocal metastases in both lobes of the liver. None of the patients had received prior systemic chemotherapy and somatostatin analogs. Only three patients had prior surgical hepatic resection.

All patients were followed up closely for acute and late toxic effects after treatment. All adverse events and serologic toxicity were assessed using the $\mathrm{Na}-$ tional Cancer Institute's Common Toxicity Criteria for adverse events (NCI CTC v 3.0). These patients were subsequently observed for survival until death or until June 1, 2011. Follow-up records for survival were obtained from clinic notes or phone calls.

All patients were initially followed up one month later and then at 3-month intervals and tumor response was evaluated by CT imaging. All CT scans were dynamic using oral and i.v. contrast with slice thickness of $3 \mathrm{~mm}$ or less. Tumor response was assessed according to Response Evaluation Criteria in Solid Tumors (RECIST) guidelines as complete response (CR), partial response (PR), stable disease (SD), or progression of disease (PD). ${ }^{10}$

Each patient was subjected to standard pretherapy evaluation as follows: History, physical examination, and baseline serology including liver function tests; pretreatment dynamic contrast-enhanced CT imaging scan of the liver; liver angiography with visceral catheterization to identify anatomic variants. In addition to these procedures, prior to Y-90 treatment, $99 \mathrm{~m}$ technetium-labeled macroaggrega- 


\begin{tabular}{|c|c|c|c|c|c|c|}
\hline Case no & Age & Sex & PT & TT & Tumor Site & Presenting symptoms \\
\hline 1 & 58 & M & - & $\mathrm{RE}$ & $\mathrm{CR}$ & Itching \\
\hline 2 & 57 & $\mathrm{~F}$ & - & $\mathrm{RE}$ & $P$ & Pain, loss of weight, excessive sweating \\
\hline 3 & 62 & $\mathrm{~F}$ & - & $\mathrm{RE}$ & U & Pain \\
\hline 4 & 47 & $\mathrm{~F}$ & S & $\mathrm{RE}$ & U & Pain \\
\hline 5 & 57 & M & S & $\mathrm{RE}$ & G & Pain, flushing \\
\hline 6 & 53 & M & - & $\mathrm{RE}$ & $P$ & Anorexia \\
\hline 7 & 65 & M & - & CE & $P$ & Pain \\
\hline 8 & 39 & M & S & CE & $U$ & Incidental mass \\
\hline 9 & 35 & $\mathrm{~F}$ & - & CE & $P$ & Pain \\
\hline 10 & 48 & M & - & CE & $P$ & Incidental mass \\
\hline 11 & 50 & $\mathrm{~F}$ & - & CE & । & Pain \\
\hline 12 & 61 & M & - & CE & $\mathrm{CR}$ & Hematochezia \\
\hline 13 & 43 & $\mathrm{~F}$ & - & CE & $P$ & Flushing, itching \\
\hline 14 & 42 & M & - & CE & G & Loss of weight, excessive sweating \\
\hline
\end{tabular}

ted albumin (99mTc-MAA) shunt evaluation was performed and; if necessary, prophylactic embolization of extrahepatic arteries was further conducted (Figure 1).

All procedures were performed by 2 experienced interventional radiologists. The preference of treatment for either radioembolization or TACE was at the discretion of the interventional radiologist who performed the procedure. However, radioembolization was commercially available only after April 2008 in the country, and therefore; TACE was the first choice until then and there was a tendency to perform radioembolization after Y 90 treatment being introduced to the practice.

All transarterial chemoembolizations were performed using a standard technique as previously described in the literature. ${ }^{11}$ In brief, a mixture of iodized oil (range, 10-20 cc) (Lipiodol, Guerbet, Aulnay-sous-Bois, France) and solution containing 50$100 \mathrm{mg}$ of doxorubicin (Adriamycin; Pharmacia and Upjohn Co, Kalamazoo, MI), 50-100 mg of cisplatin, $10 \mathrm{mg}$ of mitomycin-C (Kyowa Hakko Kogyo, Tokyo, JP) were infused into the superselective artery for single lesions, or to a lobar artery for multiple lesions. Then embolic agents either 45$150 \mu \mathrm{m}$ or $300-500 \mu \mathrm{m}$ polyvinyl alcohol particles (Contour, Boston Scientific, USA) were infused in order to reduce arterial inflow and prevent washout of the chemotherapeutic agent. In drug-eluting bead chemoembolizations $100-300$ or $300-500 \mu \mathrm{m}$ DC Beads (Biocompatibles UK, Surrey, U.K.) preloaded with $50 \mathrm{mg}$ doxorubicin were infused into superselective artery. In bland embolization 150$500 \mu \mathrm{m}$ polyvinyl alcohol particles were used.

For Y-90 treatment, after the standard workup as mentioned above including shunt evaluation via (99mTc-MAA) scintigraph and prophylactic embolization of any afferent extrahepatic arteries, Y-90 microspheres were infused at the second hepatic arterial catheterization performed 2 to 4 weeks after the first one (Figure 2). Technical details are described in the literature.? Lobar treatment planning, instead of whole liver treatment at one session was applied in all patients in the study group.

Technical success for either Y-90 or TACE treatment was determined as the skill to deliver $\geq 75 \%$ of the planned dose of therapy at each treatment. 


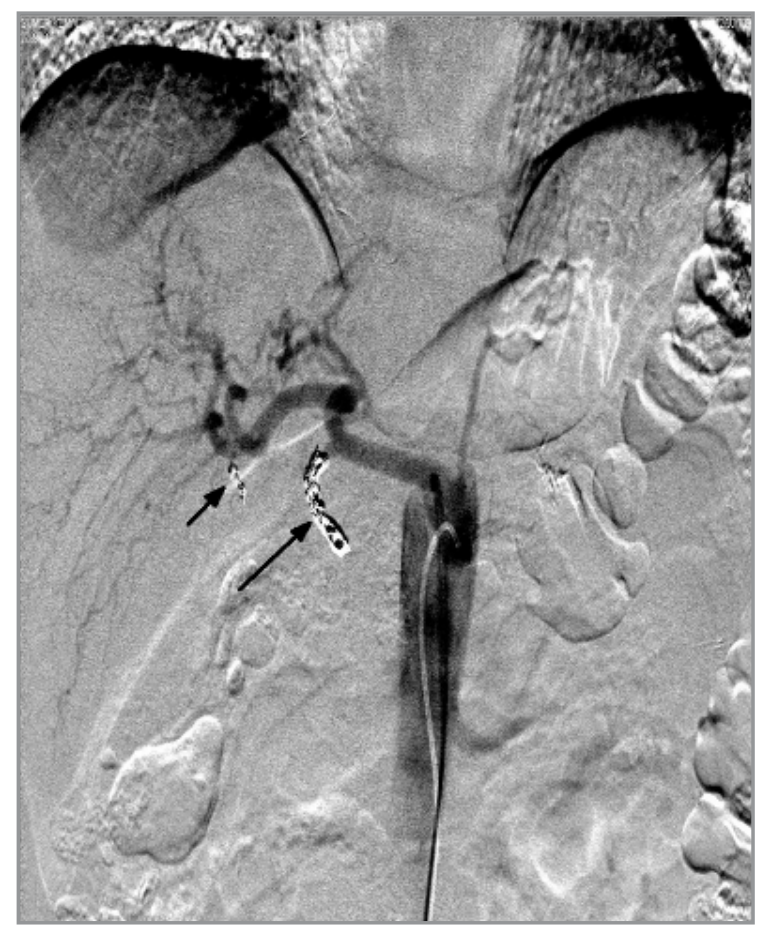

Figure 1. Common hepatic artery injection angiogram shows standard hepatic arterial anatomy and proximal coil embolization of the cystic (small arrow) and gastroduodenal artery (long arrow) to prevent non-target Y-90 embolization in case of reflux.

Once embolization was completed, each patient was hospitalized overnight. The aim of hospitalization was to observe the patients for any possible post-embolization adverse events. The mean hospital stay was 1.5 and 2.5 days for Y 90 and TACE groups respectively.

Quantitative data were expressed as the mean \pm SD and range, and qualitative data were expressed as percentages. Survival data were calculated beginning with the dates of the first TACE or Y-90 treatment and analyzed with the Kaplan-Meier method. The Mann-Whitney test was used due to asymmetric distributed continuous variables between groups. A value of $\mathrm{p}<0.05$ was considered statistically significant.

\section{RESULTS}

Fourteen patients underwent 19 treatments, 8 patients receiving 12 TACE treatment and 6 patients receiving 7 Y-90 treatment.

One patient in Y-90 and one patient in TACE group

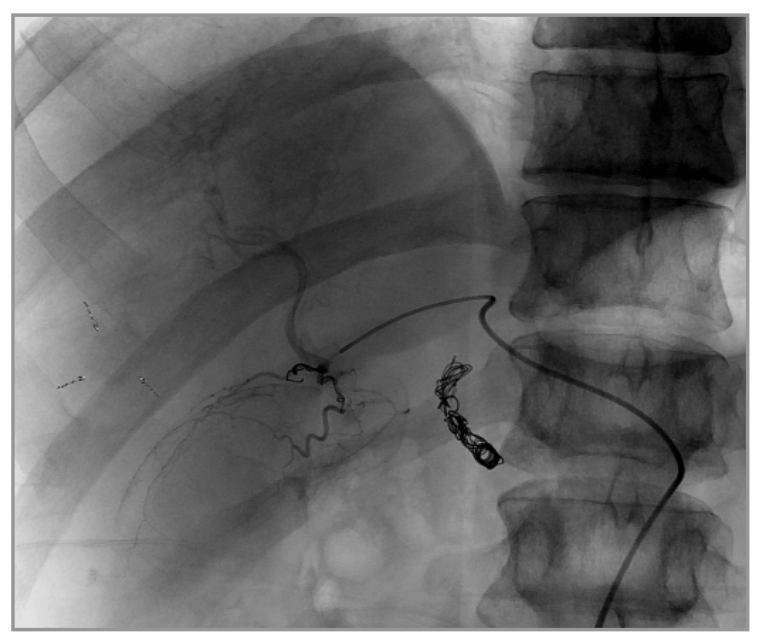

Figure 2. Selective angiogram of right hepatic artery shows small tumor blush (arrows).

had whole liver treatments in 2 sessions, and the other 12 patients had unilobar treatments initially. While 6 out of the 14 patients had single Y-90 or TACE procedure, one patient had Y-90 twice, one patient had TACE twice and 2 patients had TACE for three times. Whole liver treatments were performed by the administration of 2 adjusted separate doses into the right and left hepatic arteries. Visceral artery embolization of extrahepatic arteries was done in 4 patients prior to the radioembolization. This included embolization of the gastroduodenal artery in 4 patients, the right gastric artery in one patient, left gastric artery in one patient and cystic artery in 2 patients. The mean delivered dose of Y-90 for each session was $1.4 \mathrm{GBq}$ (range, 1.2$1.7 \mathrm{GBq})$.

All patients presented with various clinical symptoms including flushing, itching, local symptoms caused by tumor bulk (abdominal pain or mass), loss of weight, hematochezia and tenesmus. The most common clinical presentation was abdominal pain $(50 \%)$. Eight $(62 \%)$ of the patients reported relief of symptoms after the first initial of either Y-90 or TACE treatment. When evaluated according to group, four $(75 \%)$ patients of Y-90 group and four $(57 \%)$ patients of TACE group had relief of the presenting symptoms.

All treatments were technically successful. There was no major complication related to the embolization procedure. Only one patient had asymptomatic 


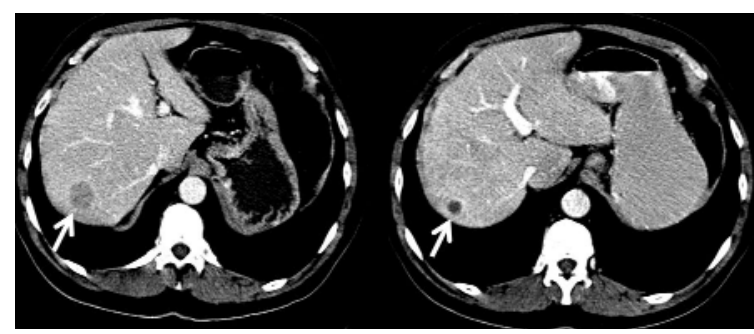

Figure 3. a, b. Axial CT scan image of a 53-year-old man shows metastatic liver lesion (arrow) from pancreatic islet cell tumor. After Y-90 treatment CT image shows more than 50\% reduction in size of tumor (arrow), which is representative of partial response.

partial right portal vein thrombosis detected in the 1-month follow up computed tomography after a single session of Y-90 therapy. No medical or interventional treatment was required. The patient subsequently did well and died 28 months after Y-90 treatment due to progressive disease. Although, almost all patients presented mild-to-moderate fatigue and fever, abdominal pain and nausea were seen in one patient after Y-90 and 4 patients after TA$\mathrm{CE}$ which all were treated with intravenous narcotics and antiemetics. These patients were evaluated as grade 1-2 toxicity according to NCI CTC v 3.0 criteria. Two patients presented with grade 3 elevation of AST, ALT on baseline examination after TACE procedure. However, all these liver function tests were returned to baseline levels in 7-10 days after embolization. There was no statistically significant change in levels of serum albumin, aspartate transaminase (AST), alanine transaminase (ALT) and total bilirubin after Y-90 treatment.

The median follow-up was 17 and 19 months in Y90 and TACE groups, respectively. Local tumor morphologic evaluations according to RECIST criteria were as follows: Total disease control (PR+

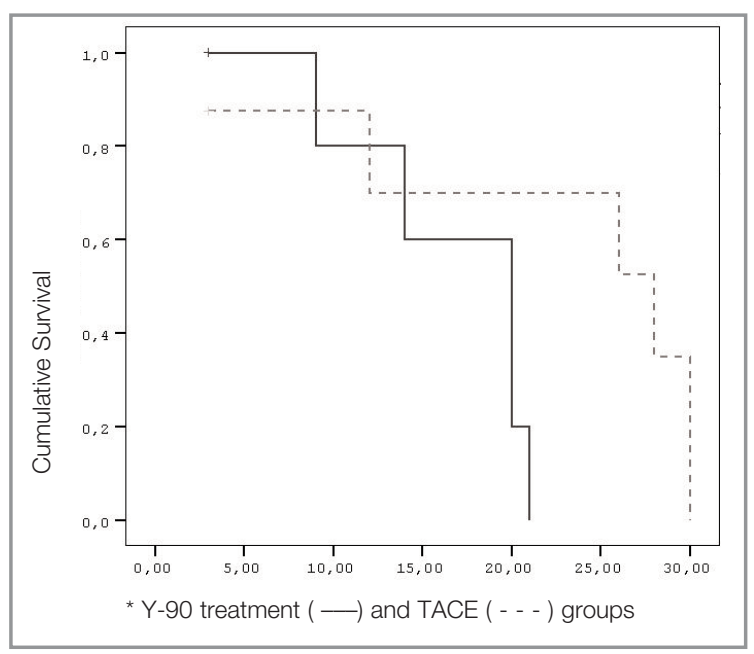

Graphic 1. Kaplan-Meier survival curve for both groups from initial therapy. Graph shows overall survival rates for Y-90 treatment $(-)$ and TACE (- - ) groups. Survival rates for subgroups are not significantly different (log-rank $p=0.09$ ).

$\mathrm{CR}+$ stable) were seen in 4 patients $(67 \%)$ and in 7 patients $(87.5 \%)$ at short-term ( $<3$ months) followup in Y-90 and TACE groups, respectively (Figure 3). At intermediate-term ( $>3$ months) follow-up, total disease control were seen in 5 patients $(83 \%)$ and in 3 patients (43\%) in Y-90 and TACE groups, respectively. Only one patient (17\%) showed progressive disease in Y-90 group, whereas 5 patients (71\%) showed progressive disease despite repeated TACE procedures in TACE group at intermediateterm ( $>3$ months) follow-up (Table 2).

The mean survival period for Y-90 treatment group was 14.5 months (range, 3-21 months) and for TACE group 16.8 months (range, 3-30 months). There was no statistically significant difference between two groups (log-rank $\mathrm{p}=0.09)$ (Graphic 1$)$. The median hepatic-specific progression-free survival du-

\begin{tabular}{|c|c|c|c|c|}
\hline \multirow[b]{2}{*}{ Treatment } & \multicolumn{2}{|c|}{ Short-Term (<3 months) } & \multicolumn{2}{|c|}{ Intermediate-Term (>3 months) } \\
\hline & Y-90 & TACE & Y-90 & TACE \\
\hline $\mathrm{CR}+\mathrm{PR}+$ Stable & $4(67 \%)$ & 7 (87.5\%) & 5 (83\%) & $3(43 \%)$ \\
\hline Progression of disease & $2(33 \%)$ & $1(12.5 \%)$ & $1(17 \%)$ & $5(71 \%)$ \\
\hline
\end{tabular}


rations were 7.5 and 18 months in Y-90 and TACE groups, respectively. Although TACE group had a longer follow-up time as well as progression-free survival duration, there was no statistically significant difference $(\mathrm{p}=0.35)$ between TACE and Y-90 groups.

One patient died 9 months and 1 patient 14 months after Y-90 treatment. However, 1 patient died 3 months, 1 patient 28 months and 1 patient 29 months after TACE therapy due to progressive extrahepatic disease in both groups. Overall, 5 patients $(36 \%)$ died at the last-time of follow-up.

\section{DISCUSSION}

Transarterial liver-directed therapy has become an important treatment modality of patients with metastatic NETs because of deriving the majority (80\%-90\%) of their blood supply from the hepatic artery. ${ }^{12}$ Previous studies of TACE and Y-90 treatment have shown $7.7-95 \%$ and $40-90 \%$ radiologic response, respectively., ${ }^{6-16}$ The initial response rates in this study in both groups are comparable favorably with previously published series. ${ }^{6,12-16}$ However, the frequency of progression of disease in TACE group at intermediate-term ( $>3$ months) follow-up was higher than reported in other interventional series. ${ }^{9,17,18}$ This condition is likely due to several reasons. First, it may have been affected by our small sample size. Second, all patients had diffuse bilobar disease at the time of the diagnosis. In contrast, $89 \%$ and $51 \%$ of the patients treated by Ho et al. ${ }^{18}$ and Gupta et al. ${ }^{19}$, respectively had diffuse liver involvement. The diffuse liver involvement in our patient population may have been a contributor to slightly lower response rates, being refractory to the treatment and also to their $14 \%$ one-year mortality in TACE group.

In one of the single-center studies including 46 patients with carcinoid and islet cell tumors, Ho et al. reported that carcinoid and islet cell tumors had similar response rates after treatment with TAE or TACE. ${ }^{18}$ However, Gupta et al. reported that patients with carcinoid tumors treated with TAE or TA$\mathrm{CE}$ had higher radiologic response rates than pancreatic islet cell tumors. ${ }^{19}$ On the contrary, in our TACE group $75 \%$ of carcinoid tumors showed progression of disease, but statistical significance was not reached due to small sample size. Moreover re- peated TACE procedures did not salvage these patients. Varker et al. performed repeated TACE to refractory cases and stated that survival and radiologic response were not different from the first TACE.$^{20}$ In these situations other regional therapies including RFA or Y-90 treatment can be used for salvation. $^{21}$

Previous studies of TACE have shown median survival times and progressive-free survival of 15-44 and 11.8-22.7 months, respectively. ${ }^{19,20,22,23}$ We found a comparable outcome in the median survival times and progressive-free survival for the TACE group as a whole being 19 months and 18 months, respectively.

Several studies of Y-90 treatment have reported median survival times and progressive-free survival of 14-70 months and 12 months, respectively. ${ }^{2,15,24,25}$ Median survival time of our Y-90 group (17 months) is comparable favorably with the published series. ${ }^{15,24}$ However, our median time to progression (TTP) (7.5 months) is lower than other studies. ${ }^{2,25}$ While this may be related to the small sample size or a reflection of other prognostic factors including gender differences, tumor differentiation. Saxena et al. have reported that female gender and well-differentiated tumor are associated with a good treatment response and/or prognosis. ${ }^{26}$ In our Y90 group, patients who showed progression of disease were male and with moderate tumor differentiation.

Systemic effects of locally given chemotherapy are inevitable in TACE. When compared radioembolization with TACE, radioembolization has less systemic toxicity. ${ }^{12}$ We observed minor side effects (fatigue, nausea) in both group. No postembolization syndrome, radiation hepatitis or veno-occlusive liver failure was seen in our patient population. Serologic toxicity (abnormal elevation of serologic markers) that may occur after any interventional procedure for hepatic disease is to be considered. ${ }^{26}$ All studies have shown an acceptable level of serologic toxicity. In our study, 2 patients $(25 \%)$ developed a grade 3 elevation of ALP and AST after TACE according to NCI CTC v 3.0.

Improving the quality of life (QOL) for many patients with NETs hepatic metastases as much as possible is as important as extending the survival. ${ }^{15}$ Yet, there have been few studies investigating the im- 
pact of aggressive locoregional therapies of liver metastases on the QOL. ${ }^{2}$ Being a retrospective study, we did not score quality of life by using a routine validated self-assessment scale (QLQ-C30, QLQ-LMC21) recommended by the European Organization for Research and Treatment of Cancer $(\text { EORTC })^{27}$ with face to face meeting. So we scored the QOL by phone calls. QOL scores are high in $75 \%$ of alive patients treated with Y-90, whereas in TACE group only $20 \%$ patients have high scores in our study. However, Kalinowski et al. have reported that although Y-90 treatment improved the QOL after radioembolization at short term, lower QOL scores were detected after one-year period. ${ }^{2}$ Future investigations with comparative locoregional therapies of liver metastases that includes a larger sample size and longer follow-up, is necessary to make definitive conclusions regarding the effect on QOL.

A limitation of our study is the retrospective nature and small sample size. A prospective randomized clinical study comparing TACE versus Y-90 treatment is difficult in single-institution studies of hepatic metastatic NETs due to the limited number of patients available. Another limitation of this study was not having serum tumor markers such as Chromogranine $\mathrm{A}$ in all patients.

From this small cohort, both Y-90 treatment and TACE have advantages and disadvantages in treatment of patients with hmNETs, however, further investigations in a controlled prospective manner are required to compare the efficiency of two treatments on response rate and survival in locoregional therapies such as radioembolization and chemoembolization of NETs hepatic metastases.

\section{REFERENCES}

1. Cirillo F. Neuroendocrine tumors and their association with rare tumors: observation of 4 cases. Eur Rev Med Pharmacol Sci 14: 577-588, 2010.

2. Kalinowski M, Dressler M, Konig A, et al. Selective internal radiotherapy with Yttrium-90 microspheres for hepatic metastatic neuroendocrine tumors: a prospective single center study. Digestion 79: 137-142, 2009.

3. Madoff DC, Gupta S, Ahrar K, et al. Update on the management of neuroendocrine hepatic metastases. J Vasc Interv Radiol 17: 1235-1249, 2006.
4. Steinmuller T, Kianmanesh R, Falconi M, et al. Consensus guidelines for the management of patients with liver metastases from digestive (neuro)endocrine tumors: foregut, midgut, hindgut, and unknown primary. Neuroendocrinology 87: 47-62, 2008.

5. Hoffmann RT, Paprottka P, Jakobs TF, et al. Arterial therapies of non-colorectal cancer metastases to the liver (from chemoembolization to radioembolization). Abdom Imaging 36: 671-676, 2011.

6. Kennedy A, Coldwell D, Sangro B, et al. Integrating Radioembolization into the Treatment Paradigm for Metastatic Neuroendocrine Tumors in the Liver. Am J Clin Oncol 35: 393-398, 2012.

7. Peynircioglu B, Cil B, Bozkurt F, et al. Radioembolization for the treatment of unresectable liver cancer: initial experience at a single center. Diagn Interv Radiol 16: 70-78, 2010.

8. Strosberg JR, Cheema A, Kvols LK. A review of systemic and liver-directed therapies for metastatic neuroendocrine tumors of the gastroenteropancreatic tract. Cancer Control 18: 127-137, 2011.

9. Gaur SK, Friese JL, Sadow CA, et al. Hepatic arterial chemoembolization using drug-eluting beads in gastrointestinal neuroendocrine tumor metastatic to the liver. Cardiovasc Intervent Radiol 34: 566-572, 2011.

10. Duffaud F, Therasse P. New guidelines to evaluate the response to treatment in solid tumors. Bull Cancer 87 : 881-886, 2000.

11. Vogl TJ, Gruber T, Naguib NN, et al. Liver metastases of neuroendocrine tumors: treatment with hepatic transarterial chemotherapy using two therapeutic protocols. AJR Am J Roentgenol 193: 941-947, 2009.

12. Nazario J, Gupta S. Transarterial liver-directed therapies of neuroendocrine hepatic metastases. Semin Oncol 37: 118-126, 2010.

13. Yao KA, Talamonti MS, Nemcek A, et al. Indications and results of liver resection and hepatic chemoembolization for metastatic gastrointestinal neuroendocrine tumors. Surgery 130: 677-682, 2001.

14. Perry LJ, Stuart K, Stokes KR, Clouse ME. Hepatic arterial chemoembolization for metastatic neuroendocrine tumors. Surgery 116: 1111-1116, 1994.

15. Kennedy AS, Dezarn WA, McNeillie P, et al. Radioembolization for unresectable neuroendocrine hepatic metastases using resin 90Y-microspheres: early results in 148 patients. Am J Clin Oncol 31: 271-279, 2008.

16. Kress $\mathrm{O}$, Wagner HJ, Wied M, et al. Transarterial chemoembolization of advanced liver metastases of neuroendocrine tumors: a retrospective single-center analysis. Digestion 68: 94-101, 2003.

17. Bloomston M, Al-Saif O, Klemanski D, et al. Hepatic artery chemoembolization in 122 patients with metastatic carcinoid tumor: lessons learned. J Gastrointest Surg 11: 264-271, 2007. 
18. Ho AS, Picus J, Darcy MD, et al. Long-term outcome after chemoembolization and embolization of hepatic metastatic lesions from neuroendocrine tumors. AJR Am J Roentgenol 188: 1201-1207, 2007.

19. Gupta S, Johnson MM, Murthy R, et al. Hepatic arterial embolization and chemoembolization for the treatment of patients with metastatic neuroendocrine tumors: variables affecting response rates and survival. Cancer 104: 1590-1602, 2005.

20. Varker KA, Martin EW, Klemanski D, et al. Repeat transarterial chemoembolization (TACE) for progressive hepatic carcinoid metastases provides results similar to first TACE. J Gastrointest Surg 11: 1680-1685, 2007.

21. Rhee TK, Lewandowski RJ, Liu DM, et al. 90Y Radioembolization for metastatic neuroendocrine liver tumors: preliminary results from a multi-institutional experience. Ann Surg 247: 1029-1035, 2008.

22. Kim YH, Ajani JA, Carrasco CH, et al. Selective hepatic arterial chemoembolization for liver metastases in patients with carcinoid tumor or islet cell carcinoma. Cancer Invest 17: 474-478, 1999.

23. Ruutiainen AT, Soulen MC, Tuite CM, et al. Chemoembolization and bland embolization of neuroendocrine tumor metastases to the liver. J Vasc Interv Radiol 18: 847-855, 2007.

24. Murthy R, Kamat P, Nunez R, et al. Yttrium-90 microsphere radioembolotherapy of hepatic metastatic neuroendocrine carcinomas after hepatic arterial embolization. J Vasc Interv Radiol 19: 145-151, 2008.

25. Liu DM, Kennedy A, Turner D, et al. Minimally invasive techniques in management of hepatic neuroendocrine metastatic disease. Am J Clin Oncol 32: 200-215, 2009.
26. Saxena A, Chua TC, Bester L, et al. Factors predicting response and survival after yttrium-90 radioembolization of unresectable neuroendocrine tumor liver metastases: a critical appraisal of 48 cases. Ann Surg 251: 910-916, 2010.

27. Aaronson NK, Ahmedzai S, Bergman B, et al. The European Organization for Research and Treatment of Cancer QLQ-C30: a quality-of-life instrument for use in international clinical trials in oncology. J Natl Cancer Inst 85: 365-376, 1993.

\section{Correspondence}

\section{Dr. Fuat OZKAN}

Kahramanmaraş Sütçü Imam Üniversitesi

Tıp Fakültesi

Radyoloji Anabilim Dalı

Yörükselim

KAHRAMANMARAS / TURKEY

Tel: (+90.344) 2212337 / Ext189

Fax: (+90.344) 2212371

e-mail: drfozkan@yahoo.com 